\title{
The Birth of an Empire of Two Churches: Church Property, Theologians, and the League of Schmalkalden
}

\author{
CHRistopher OCKer
}

$\mathrm{D}$ id the creation of Protestant churches in Germany during Luther's generation follow someone's intentions? Heiko Oberman, appealing to a medieval Luther, portrays the reformer as herald of a dawning apocalypse, a monk at war with the devil, who expected God to judge the world and rescue Christians with no help from human institutions, abilities, and processes. ${ }^{1}$ This Luther could not have intended the creation of a new church. Dorothea Wendebourg and Hans-Jürgen Goertz stress the diversity of early evangelical movements. Goertz argues that anticlericalism helped the early Reformation's gamut of spiritual, political, economic, and social trends to coalesce into moderate and radical groups, whereas Wendebourg suggests that the movements were only united in the judgment of the Counter Reformation. ${ }^{2}$

Many scholars concede this diversity. "There were very many different Reformations," Diarmaid McCulloch has recently observed, aimed "at recreating authentic Catholic Christianity." 3 But some intention to form a new church existed, even if the intention was indirect. Scholars have identified the princely reaction to the revolting peasants of 1524-1525 as the first impetus toward political and institutional Protestantism. ${ }^{4}$ There was a

\footnotetext{
${ }^{1}$ Heiko A. Oberman, Die Wirkung der Reformation: Probleme und Perspektiven, Institut für Europäische Geschichte Mainz Vorträge 80 (Wiesbaden, 1987), 46; idem, Luther: Man between God and the Devil (New York, 1992), passim; idem, "Martin Luther zwischen Mittelalter und Neuzeit," in Die Reformation: Von Wittenberg nach Genf (Göttingen, 1987), 189-207; Scott Hendrix, "More Than a Prophet': Martin Luther in the Work of Heiko Oberman," in The Work of Heiko A. Oberman: Papers from the Symposium on His Seventieth Birthday, ed. T. A. Brady, K. G. Brady, S. KarantNunn, and J. D. Tracy (Leiden, 2003), 21-22; Bernd Hamm, “An Opponent of the Devil and the Modern Age: Heiko Oberman's View of Luther," in The Work of Heiko A. Oberman, 38, 40.

${ }^{2}$ Dorothea Wendebourg, "Die Einheit der Reformation als historisches Problem," B. Hamm, B. Moeller, and D. Wendebourg, Reformations-Theorien. Ein kirchenhistorischer Disput über Einheit und Vielfalt der Reformation (Göttingen, 1995), 31-51; Hans-Jürgen Goertz, Pfaffenhaß und groß Geschrei. Die reformatorischen Bewegungen in Deutschland, 1517-1529 (Munich, 1987), 244-250; idem, Antiklerikalismus und Reformation. Sozialgeschichtliche Untersuchungen (Göttingen, 1995), 18-20.

${ }^{3}$ Diarmaid McCulloch, The Reformation: A History (New York, 2003), 17, my emphasis.

${ }^{4}$ Peter Blickle, Die Reformation im Reich (Stuttgart, 1982), 141. Bernd Hamm has pointed to the postwar "theological and practical stress on the divinely legitimated secular office to care for the ordering of the Church and the ecclesiastical office of the minister of the Church, educated at university and legally appointed-i.e. with
} 
counterrevolutionary purpose to postwar visitations and church orders. At the same time, where religious ideas shaped distinct political attitudes, ideas were not likely to remain subservient to aims of the state. Their connection to state building, or city-state building, or confessional state building, remained encumbered by the religious imaginary and its priorities-not least, the eternal salvation of the faithful. ${ }^{5}$

Doctrines of salvation among southern city theologians, says Peter Blickle, encouraged a communal ideology based on a concept of godly law, an alternative to Luther's princely ideology, which has also been associated with an aborted republican movement. ${ }^{6}$ If progress was the goal, that progress can be called a medieval notion, rather than a modern one. Oberman points to humanists, such as Erasmus and Melanchthon, and to urban reformers generally as the sustainers of a nonapocalyptic, medieval, and progressive reform tradition. ${ }^{7}$ Yet in spite of this diversity of Reformations, everyone finds it "fairly certain" that, one way or another, "Protestant theology could provide important ideological support for the evolving state." How?

Not necessarily by a kind of Wittenberg effect. In the case of the Protestant princes, given the Elector of Saxony's prominence among them, Wittenberg theologians clearly played a crucial role in the consolidation of Protestant movements and doctrines. But one must still circumscribe their part in the emerging Protestant state. If they did make ideological space for temporal power, as some believe, it was not by inventing a univocal, religious rationale for the temporal government of the church, nor by providing a rationale for the absolute power of princes. ${ }^{9}$ By distinguishing between divine salvation and all forms of law-a spiritual realm under the Gospel and a legal realm under temporal rulers-Luther and Melanchthon seemed to assign supervision of the material church to temporal power, which could then use church property for its own purposes, be it to build clientage, provide welfare, relieve debt, or repair fortifications, while schools and territorial churches could serve as the engines of popular

the support of the civic authorities." Bernd Hamm, The Reformation of Faith in the Context of Late Medieval Theology and Piety, ed. Robert J. Bast (Leiden, 2004), 218-19.

${ }^{5}$ For communalization and its variable relationship to evangelical preaching, see Tom Scott, Town, Country, and Regions in Reformation Germany (Leiden, 2005), 56-75, 125-148. For city-states in Germany, consider Tom Scott, "The City-State in German Speaking Lands," in Politics and Reformations: Communities, Polities, Nations, and Empires-Essays in Honor of Thomas A. Brady, Jr., ed. C. Ocker, M. Printy, P. Starenko, and P. Wallace (Leiden, 2007), 3-65.

${ }^{6}$ Peter Blickle, Die Reformation im Reich, 141; idem, Communal Reformation: the Quest for Salvation in SixteenthCentury Germany, trans. T. Dunlap (New Jersey, 1992), 111-52; idem, The Revolution of 1525: The German Peasants' War from a New Perspective, trans. T. A. Brady and E. C. E. Midelfort (Baltimore, 1981), 145-54; Thomas A. Brady, Turning Swiss: Cities and Empire, 1450-1550 (New York, 1985). Consider also Tom Scott in the previous note and, for the case of federalism in the imperial diet, see Gabriele Haug-Moritz, "Zwischen Spätmittelalter und Reformationpolitischer Föderalismus im Reich der Reformationszeit," in Politics and Reformations (see note 5), 513-37.

${ }^{7}$ Oberman, "Martin Luther zwischen Mittelalter und Neuzeit," 204-6. Hamm, “An Opponent of the Devil," 41.

${ }^{8}$ My emphasis. For the quotation, see Robert W. Scribner and C. Scott Dixon, The German Reformation, 2 nd ed. (London, 2003), 80. Consider also pp. 37-42.

${ }^{9}$ Contra William Montgomery McGovern, From Luther to Hitler (New York, 1941); Herbert Marcuse, Ideen zur einer kritischen Theorie der Gesellschaft (Frankfurt, 1969), 57-58; Carlton J. H. Hayes, Christianity and Western Civilization (Stanford, 1954), 32-36. For various critiques of the association of Luther with absolutism, consider Thomas Kaufmann, "Luther zwischen Wissenschaftskulturen," in Luther zwischen den Kulturen, ed. H. Medick and P. Schmidt (Göttingen, 2004), 475-78; Klaus Deppermann, Protestantische Profile von Luther bis Francke (Göttingen, 1992), 14; James Tracy, "Luther and the Modern State: Introduction to a Neuralgic Theme," in Luther and the Modern State in Germany, ed. J. D. Tracy (Kirksville, MO, 1986), 9-19. For problems with the association of Melanchthon with absolutism, see James Estes' discussion of this view and its problems: James Martin Estes, Peace, Order and the Glory of God: Secular Authority and the Church in the Thought of Luther and Melanchthon, 1518-1559 (Leiden, 2005), xii with n. 7. 
acculturation to the confessional state. Catholic princes, in the now common view, pursued a course similar in effect, if less confrontational to the church's legal authority. ${ }^{10}$

This involves something different than a unifying political theology. A Wittenberg dichotomy of spiritual and worldly things can imply (and has implied) that Luther actually nullified the role of theologians in politics, leaving the religious controversy more or less incidental to the long-term development of territorial rule. ${ }^{11}$ The most overt temporal interference in church affairs, and a crucial test-case of Protestant political ambitions, was the confiscation of church property; and this, too, could seem to reinforce such religious indifference to politics. Confiscation followed traditional patterns, not new ones created by evangelical doctrine or polemic, as Walter Ziegler has pointed out. ${ }^{12}$ Nor did confiscation as such make a prince reformed, as Protestant clergy on occasion reminded the League of Schmalkalden. ${ }^{13}$ The most effective rulers to interfere in the church's material affairs in that age were Catholic - the Habsburg rulers of Catholic Spain and the Netherlands. ${ }^{14}$

Confiscations of church property provide an opportunity to study what was, as the variety of opinion on the consolidation of reform may suggest, a serendipitous movement toward an empire of two churches. Occupying a nodal point in the politics of reform, confiscations are an indicator of temporal sovereignty, as Barbara Henze has recently

\footnotetext{
${ }^{10}$ Eike Wolgast, Hochstift und Reformation (Stuttgart, 1995); idem, Die Wittenberger Theologie und die Politik der evangelischen Stände. Studien zu Luthers Gutachten in politischen Fragen (Gütersloh, 1977); Johannes Heckel, Cura Religionis. Ius in Sacra. Ius circa Sacra (Darmstadt, 1962). James Estes has corrected exaggerated views of Luther and Melanchthon's defense of unbridled temporal power: Estes, Peace, Order and the Glory of God, passim. For confessional state building, see Heinz Schilling, "Confessional Europe," Handbook of European History, 2 vols., ed. Thomas A. Brady, Heiko A. Oberman, and James D. Tracy (Leiden, 1995), 2:641-81.

${ }^{11}$ Karlheinz Blaschke has argued that the Reformation provided an opportunity for increased bureaucratic control of society by the state, but a state in transition from "the territorial dominion of the Middle Ages to the territorial state of the early modern era." He concludes, "The Reformation tied these together. It advanced the construction of the territorial state, while the rising territorial state fostered-not to say, made possible-the victory of the Reformation." Karlheinz Blaschke, “The Reformation and the Rise of the Territorial State," in Luther and the Modern State in Germany (see note 9), 74-75. Ernst Schubert has pointed out that the transition from medieval dominion to state in fact took place in a much longer time frame, and it was not very far advanced in the first half of the sixteenth century. Ernst Schubert, "Vom Gebot zur Landesordnung," in Die deutsche Reformation zwischen Spätmittelalter und Früher Neuzeit, Schriften des Historischen Kollegs. Kolloquien 50, ed. Thomas A. Brady, with the assistance of Elisabeth Müller-Luckner (Munich, 2001), 19-61. Martin Heckel has argued that after 1555 there developed a confessionally neutral state-law for the church, whereas common law absorbed canonical norms. Martin Heckel, Staat und Kirche nach den Lehren der evangelischen Juristen Deutschlands in der ersten Hälfte des 17. Jahrhunderts (Munich, 1968), 71-72. Consider also Jörn Sieglerschmidt, Territorialstaat und Kirchenregiment (Cologne, 1987), 126-29, 283-85; Gerhard Ritter, Luther. Gestalt und Symbol (Munich, 1925), 114, 159; Deppermann, Protestantische Profile von Luther bis Francke, 9-10, 16-29. Voltaire, Diderot, and Hume thought that the religious controversy was a squabble between Dominicans and Augustinian Hermits, the religious orders of Tetzel and Luther. See A. G. Dickens and John M. Tonkin, The Reformation in Historical Thought (Cambridge, 1985), 112, 128, 138.

${ }^{12}$ For the political importance of church property, see Thomas A. Brady, Protestant Politics: Jacob Sturm (14891553) and the German Reformation (Atlantic Highlands, 1995), 162-74; Walter Ziegler, "Reformation und Klosterauflösung. Ein ordensgeschichtlicher Vergleich," Reformbemühungen und Observanzbestrebungen im spätmittelalterlichen Ordenswesen, ed. Kaspar Elm (Berlin, 1989), 597-98.

${ }^{13}$ For example, a clergy memorandum published by the Schmalkald diet of Frankfurt in April 1539, Stadtarchiv Braunschweig, B III 5:5 f. 589r-v.

${ }^{14}$ Jochen A. Fühner, Die Kirchen- und die antireformatorische Religionspolitik Kaiser Karls V. in den siebzehn Provinzen der Niederlande, 1515-1555 (Leiden, 2004), 89-165. For the emperor's faith, see Fühner, Die Kirchenund die antireformatorische Religionspolitik, 167-72, and Heinz Schilling, "Charles V and Religion: The Struggle for the Integrity and Unity of Christendom," Charles V, 1500-1558, and His Time, ed. Hugo Soly and Wim Blockmans (Antwerp, 1999), 285-363, esp. 296-328.
} 
emphasized. ${ }^{15}$ They reveal a ruler's ability to interfere with the patronage rights of foreigners and seigneurs at home-the ability to dominate others in a specific place. Confiscation carried tremendous symbolic weight, violating the protected sanctity of church property while undermining the claims of Europe's most articulate sovereign, who ruled a spiritual empire from Rome. The papacy, in defending the church's (somewhat hypothetical) independence from all other temporal powers, had prompted the first detailed philosophical discussions of sovereignty in Europe over two hundred years before penitential abuse stirred Luther's conscience. In northern Europe in the 1520s and 1530s, these discussions were still waiting to be separated from the question of church power by a Bodin, an Althusius, or a Grotius. ${ }^{16}$

Confiscations threatened both papal sovereignty (as it had been debated over the previous two hundred years) and a temporal order that granted privilege to the position of the church, not as a consequence of a concept of the territorial state, but as a practical consequence of religious controversy. Confiscations also afford a lateral view of religious politics across territories, the emerging confessions, and competing political ambitions, as any examination of the property debate in the League of Schmalkalden demonstrates. In that debate, Protestant theologians made a specific political contribution, which posed not as a new ideology, but as a defense of the prerogatives of the church. Protestant clergy presented themselves and their rulers as discriminating defenders of religious tradition. The clergy tried to limit the designs of temporal rulers on church things, while also encouraging rulers to divest clergy loyal to Rome. Religious principle thus came to play a surprisingly important, practical role in the politics of church property and in the formation of an empire of two churches.

\section{The League of Schmalkalden and Church Property}

The League of Schmalkalden was preoccupied with church property from the time of its birth at the end of 1530. The most pressing threat against its first members was not war. The emperor and the archduke of Austria, bogged down by campaigns against the Ottomans and the French, were anxious for broad German support and were in no position to undertake a German war. The most pressing threat against the League was a newly revitalized Imperial Chamber Court. Near the conclusion of the imperial Diet of 1530, after the breakdown of negotiations over the religious controversy (and after the Landgrave of Hesse and the Elector of Saxony left the Diet), the imperial estates made their demands. They insisted on the restitution of church properties and repositioned the court to serve as the clearinghouse for lawsuits against Protestants who had taken over the properties of monasteries or reassigned church incomes in violation of the rights of church patrons. ${ }^{17}$

\footnotetext{
${ }^{15}$ Barbara Henze, “Orden und ihre Klöster in der Umbruchszeit der Konfessionalisierung," Die Territorien des Reichs im Zeitalter der Reformation und Konfessionalisierung. Land und Konfession 1500-1650, 7 vols., ed. A. Schindling and W. Ziegler (Münster, 1991-1996), 7:91-02.

${ }^{16}$ Michael J. Wilks, The Problem of Sovereignty in the Later Middle Ages (Cambridge UK, 1963); J. H. Burns, Lordship, Kingship, and Empire. The Idea of Monarchy, 1400-1525 (Oxford, 1992), 97-123; Franceso Ercole, "Impero e papato nella tradizione giuridica Bolognese e nel diritto pubblico Italiano del Rinascimento (sec. xiv$\mathrm{xv),"} \mathrm{Atti} \mathrm{e} \mathrm{memorie} \mathrm{della} r$. deputazione di storia patria per le provincie de Romagna series 4, vol. 1 (Bologna, 1911), 1-233.

${ }^{17}$ Legation Lorenzo Campeggios 1530-1531 und Nuntiatur Girolamo Aleandros 1531 part 1, supplementary vol. 1 of Nuntiaturberichte aus Deutschland, 1533-1559, nebst ergänzenden Aktenstücken (Tübingen, 1963), 106, 138, 141, nos. 27, 34, 36. For the reorganization of the court, see Klaus Mencke, Die Visitationen am Reichskammergericht im 16. Jahrhunmdert (Cologne, 1984), 41-44. Charles V demanded in 1530 that the Protestant estates comply by 15 April
} 
Restitution cases had been multiplying before all manner of ecclesiastical and temporal courts. Even though the revitalized Imperial Chamber Court's power to coerce was greatly limited (plaintiffs could not expect the court to end a case but found its decision a useful tool in ongoing conflicts), ${ }^{18}$ the new Protestant League stationed two procurators at Speyer to protest the court's competence in religious matters. ${ }^{19}$ This protesting adapted a tactic that Martin Luther himself began early in the religious controversy, namely, his appeal to a general council in 1518 and again in $1520 .^{20}$ The emperor soon supported such a council to resolve the religious controversy, first in 1524, while also repeatedly insisting that papal and imperial judgments against Luther be fulfilled. Members of the emperor's inner circle promoted the general council, the imperial Diet of Speyer in 1526 endorsed it, the protesting estates at Speyer in 1529 appealed to it, and the new League of Schmalkalden appealed to it, too. ${ }^{21}$

These appeals helped keep the controversy in a prolonged state of suspended animation, which was useful to contending parties, contention being endemic to a state with significant representation but low governmental capacity-in this case, the community of estates comprising the Holy Roman Empire. ${ }^{22}$ Pope Paul III was the first to try seriously to summon a general council, at Mantua, soon after his coronation in 1534, although the council only opened at Trent a decade later. And no sooner had Pope Paul issued his first invitations than did Martin Luther and his colleagues challenge conciliar authority. ${ }^{23}$ By then, appeals to a church council had served their political purpose. The appeals helped establish the controversy as a religious matter falling to ecclesiastical rather than temporal jurisdiction, to a council rather than to an imperial or other secular court.

The League tried to recuse the Imperial Chamber Court. When the 1532 Truce of Nuremberg failed to end restitution suits, legal maneuvering intensified, prolonging cases by alleging the court's prejudice and incompetence in religious matters. The League (1) tried various ways to weaken the court's influence, (2) expanded its own membership and assumed, by 1538, a

1531 with Catholic practice on the points of disagreement, while he also indicated that he would try to arrange for a church council with the pope. Thomas Fuchs, Konfession und Gespräch. Typologie und Funktion der Religionsgespräche in der Reformationszeit (Cologne, 1995), 363-88.

${ }^{18}$ Filippo Ranieri, Recht und Gesellschaft im Zeitalter der Rezeption, 2 vols. (Cologne, 1985), 1:130, 198-99; Bernhard Diestelkamp, Recht und Gericht im Heiligen Römischen Reich (Frankfurt, 1999), 257.

${ }^{19}$ Die Schmalkaldischen Bundesabschiede, 1530-1532, ed. Ekkehart Fabian (Tübingen, 1958), 18-23. For their power of attorney (9 June 1531), see Ekkehart Fabian, ed., Urkunden und Akten der Reformationsprozesse, part 1: Allgemeines 1530-1534 (Tübingen, 1961), 31-34 no. 4. For the League's use of the court in defense against legal attack, see HaugMoritz, Der Schmalkaldische Bund, 277-87. For the work of procurators, see R. M. Sprenger, Viglius van Aytta und seine Notizen über Beratungen am Reichskammergericht (1535-1537) (Nijmegen, 1988), 58-60.

${ }^{20}$ Martin Brecht, Martin Luther, 3 vols. (Minneapolis, 1985-1993), 1:239-73, 306-7 for this and the following, and Hans-Jürgen Becker, Die Appellation vom Papst an ein allgemeines Konzil (Cologne, 1988), 244-60.

${ }^{21}$ Charles-Joseph Hefele, J. Hergenroether, and H. Leclercq, Histoire des conciles, 11 vols. (Paris, 1907-1952), 8:1145; Wolfgang Reinhard, "Die Kirchenpolitischen Vorstellungen Kaiser Karls V., ihre Grundlagen und ihr Wandel," in Confessio Augustana und Confutatio. Der Augsburger Reichstag 1530 und die Einheit der Kirche, ed. Erwin Iserloh (Münster, 1980), 62-100, 70-86; Armin Kohnle, Reichstag und Reformation (Gütersloh, 2001), 266-69; Fabian, Die Schmalkaldischen Bundesabschiede, 1530-1532, 18-23.

${ }^{22}$ Adapting Charles Tilly, The Politics of Collective Violence (New York, 2003), 44-50.

${ }^{23}$ Martin Luther, Die Lügend von St. Johannes Chrysostomo (1537), D. Martin Luthers Werke, kritische Gesamtausgabe (hereafter WA), 4 parts, 127 vols. (Weimar, 1883-), 50:52-54, and the treatises gathered in vol. 50. Consider also Antonius Corvinus's 1537 challenge to conciliar authority, Georg Geisendorf, Bibliotheca Corviniana. Eine bibliographische Studie (Nieuwkoop, 1964), no. 106, and Philip Melanchthon's 1537 treatise, De ecclesia et de auctoritate verbi Dei, Corpus Reformatorum, ed. C. G. Bretschneider et al., 88 vols., (Halle, 18351906), 23:595-642. 
dominant position in the north, and (3) navigated a course with, through, or around the aggressive ambitions of the Elector of Saxony, who tried to use the exemptions granted to religious cases (the basis of the recusation of the Imperial Chamber Court) in several other expansionist campaigns, dragging the League along with him. It is difficult to describe how all this happened, in part because the League as a body never embraced a coherent set of political goals, beyond the one named in its constitution: defense of the faith of the Augsburg Confession, and hence, by clear implication, the preservation of property gains from churches. ${ }^{24}$

Charles and Ferdinand answered the League's growth with a series of concessions, including a temporary suspension of restitution suits before the Imperial Chamber Court and the famous religious colloquies of 1540 and $1541 .^{25}$ The negotiations of 1540 and 1541 provided the League's cities and princes with a tremendous opportunity, not merely to defend their doctrines before the imperial estates' choice intellectuals (no one could reasonably expect to convert anyone), but also to draw a line in the sand at church property, which they simply refused to discuss. The League achieved this by publishing a common position on confiscated properties at its diet in the spring of 1540 and by precluding negotiation over property when it answered the emperor's invitation to the religious dialogue. ${ }^{26}$ In imperial circles, it had long been suspected that at least some of Luther's supporters would abandon the schism if they were granted the properties they had confiscated. ${ }^{27}$

The emperor was, of course, very enterprising himself, when it came to church property, having expanded his rights to it in Spain and the Netherlands. He was also very devout and no lover of the Imperial Chamber Court, which generally helped the estates circumvent the emperor's personal justice. The emperor eventually suspended the Imperial Chamber Court in 1543, and the imperial Diet confirmed the suspension in 1544. This outcome amounted to de facto recognition of Protestant churches, as Thomas A. Brady, Jr. has pointed out. ${ }^{28}$ Although he destroyed the League in the brief war of 1546-1547, the emperor had set a strong precedent by his earlier concessions, in particular, the end of legal action against Protestant sequestrators in 1543. Postwar negotiations in effect restored the status quo ante that the politicians of the League created. The empire accepted the property changes undergirding the evangelical reorganization of churches before 1552 (before the Peace of Passau), despite the heresy of the Protestant faith. ${ }^{29}$ This set the stage for ongoing property disputes all the way to the Peace of Westphalia. ${ }^{30}$

\footnotetext{
${ }^{24}$ The best accounts are Brady, Protestant Politics, 142-327, and Haug-Moritz, Der Schmalkaldische Bund, 43-92. I make my own attempt in Church Robbers and Reformers, 112-31.

${ }^{25}$ Ocker, Church Robbers and Reformers, 238-56.

${ }^{26}$ Haug-Moritz, Der Schmalkaldische Bund, 536-37.

${ }^{27}$ In 1531, the papal nuncio Girolamo Aleandro suggested that Philip of Hesse would abandon the schism if he could retain the properties he confiscated, and the legate Lorenzo Campeggio, trying to mobilize the emperor to make war on the Protestants, suggested the war could be funded by church property. Legation Lorenzo Campeggios 1530-1531 und Nuntiatur Girolamo Aleandros 1531 part 1, supplementary vol. 1 of Nuntiaturberichte aus Deutschland, 1533-1559, nebst ergänzenden Aktenstücken (Tübingen, 1963), 427 no. 120, 253 no. 71.

${ }^{28}$ Brady, Protestant Politics, 169-74. Körber and Sieglerschmidt have also noted that the imperial Diet of 1544 anticipated the permanent settlement of 1555. Sieglerschmidt, Territorialstaat, 155; Kurt Körber, Kirchengüterfrage und Schmalkaldischer Bund. Ein Beitrag zur deutschen Reformationsgeschichte (Leipzig, 1913), 148.

${ }^{29}$ Anton Schindling, "Der Passauer Vertrag und die Kirchengüterfrage," in Der Passauer Vertrag von 1552. Politische Entstehung, reichsrechtliche Bedeutung und konfessionsgeschichtliche Bewertung, ed. Winfried Becker (Neustadt a.d. Aisch, 2003), 105-23, here 108.

${ }^{30}$ Sieglerschmidt, Territorialstaat und Kirchenregiment, 160-67, 173; Bernhard Ruthmann, Die Religionsprozesse am Reichskammergericht (1555-1648) (Köln, 1996), 484-580 and passim.
} 


\section{Theologians and the League of Schmalkalden}

Theologians played an important role in the League's strategy for the simple reason that the League needed confiscations to be defined as religious deeds, performed to advance religion, and not as mere sequestrations in the technical sense (the protective custody of property during a dispute). ${ }^{31}$ Clergy defined the religion; and until a general council condemned evangelical doctrines, such confiscations were legally justifiable as protective actions, or as actions meant to protect a reforming Catholic Church.

Defining the religious purpose of confiscations might have been fairly straightforward, had the new theologians developed trans-regional structures of religious authority or a new theory about church management. They did not. Instead, they relied on consensus-building among university-trained men as occasion arose.

Occasion first arose before, during, and after the Peasants' War of 1524-1525. At the beginning, evangelical theologians entertained a variety of approaches and answers to the question of church property. There was the early suggestion that the city of Leisnig should use properties controlled by the Cistercians of Buch to support evangelical pastors and create a poor chest (Luther in 1522). The contrary point was also made: that a prince must not assign a church income to an evangelical pastor against the wishes of the church's Catholic patron (in this case, the collegiate chapter of Eisenach-Luther's point in October 1525). Yet another suggestion was that a prince should use church endowments to install and pay evangelical preachers (also Luther's point in 1525). Another argument held that a prince should require communities to fund their new pastors, and only where the people were too poor could cloister property be used for this purpose (also Luther's point, in 1526). ${ }^{32}$

When the Palatine Elector asked Johannes Brenz, evangelical preacher in Schwäbisch Hall, to answer the famous twelve articles of the 1525 revolt, Brenz offered the opinion that a territorial prince supporting an evangelical appointment could trump the claim of a foreign Catholic patron. ${ }^{33}$ But this gesture toward such a prince's territorial sovereignty was impractical. When two years later the Swabian League tried to pressure its members to capture runaway monks and nuns, Johannes Brenz authored a memorandum for Schwäbisch Hall complaining that the emperor illegally forced the League to interfere in religion. No one, he explained, could bind the conscience of a city council in religious matters. That is, the division between spiritual and secular jurisdictions was absolute. ${ }^{34}$ Of course, Brenz made this point in support of the council's defense of evangelical preaching, e.g., a temporal authority's religious interventions (Luther taught that such preaching would create monastic attrition, which would leave empty cloisters, which rulers could then take into protective custody).

The red thread running through all advice was the promotion of evangelical preaching, whether by the exercise of an evangelical sympathizer's power or by the limitation of an opponent's power. Theologians must have remembered what Melanchthon, since 1521, or Erasmus before him, had taught them: that temporal authority must care for religion. ${ }^{35}$

\footnotetext{
${ }^{31}$ Conrad Lagus, Iuris utriusque traditio methodica (Frankfurt, 1543), ff. 96v-97r for the definition of sequestration.

${ }^{32}$ For Leisnig, WA 11:401-16; 12:1-30; Sieglerschmidt, Territorialstaat, 223-54. For Eisenach, D. Martin Luthers Werke, kritische Gesamtausgabe, Section 4, Briefwechsel (hereafter WABr), 3:274-75 no. 732. For the responsibility of communities to pay for pastors, WABr 4:133-34 no. 1052.

${ }^{33}$ Johannes Brenz, Rhattschalg und Guttbedunckhen herrn Johann Brentii über der Bauren gestelte und für Euangelische dargegebene Zwölf Articul Ahn Pfaltzgraff Ludwigen bey Rein, Churfursten, in Johannes Brenz, Werke, ed. Martin Brecht and Gerhard Schäfer, 3 vols. (Tübingen, 1970), 1/1:132-74, here 144-47.

${ }^{34}$ Brenz, Werke, $1 / 2: 197-210$.

${ }^{35}$ Estes, Peace, Order and the Glory of God, 53, 55-58.
} 
Or in other words, a ruler should be religious in the context of one's estate. Theological advice was not based on a concept of temporal power per se, but on a concept of good religion. It was necessary to portray the old faith and monasticism as religious malpractice. ${ }^{36}$

Once the League of Schmalkalden was formed, a consensus on church property gradually took shape among theologians associated with the League's members. Princes like Philip of Hesse, whose confiscations in 1527 set an early benchmark for evangelical churchplundering, defended their actions as defense of religion, as protecting the church from the malpractice of priests, monks, and nuns-an extension of their jurisdiction over churches, the Kirchenvogtei. ${ }^{37}$ They ignored any supervening protective role in the church that the emperor might claim. The clergy generally did not want to imply a free extension of territorial sovereignty over churches (for example, Luther to the Elector of Saxony in 1531). ${ }^{38}$ Early advice to members of the League limited intervention to the ruling authority's sphere of church patronage (for example, Hessian and Saxon theologians to the city of Bremen in 1533, Wittenberg theologians to the city of Augsburg in 1536, and Luther and Melanchthon to Frankfurt am Main in 1535). ${ }^{39}$

Mutual Catholic-Protestant recognition of patronage rights was promoted by the League of Schmalkalden's diet in December 1535 and by the Landgrave of Hesse. ${ }^{40}$ One could think of this as a confessionally equitable position. Or one could call it a position that preserved the baseline of respect required by participation in the community of estates that was the Holy Roman Empire. Theologians only granted rulers a free hand in church property when property remained after the needs of schools, poor relief, and public welfare had been met. That was hardly a radical point of view. It was established in both canon law and Roman law. ${ }^{41}$ In fact, in Roman law, the common welfare to which church property could be applied included relief from such princely burdens as debt or the payment of ransom. ${ }^{42}$ Protestants had not moved the theoretical question of temporal power in the church forward at all.

In other words, there was considerable ambiguity to be found in theological advice from the late 1520 s and early 1530 s, when confiscations seemed difficult and often tenuous. Before 1535, evangelical theologians worried more about failed confiscations than overly successful ones. The

\footnotetext{
${ }^{36}$ For example, in briefs composed in connection with the 1530 imperial Diet by Hessian theologians and by the evangelical preachers of Nürnberg. Richard Andrew Cahill, Philipp of Hesse and the Reformation (Mainz, 2001), 141-50, 152; Köhler, “Actenstücke der hessischen Reformationsgeschichte," Zeitschrift für historische Theologie 37 (1867): 217-47, here 217-20, 222-44; Quellen und Forschungen zur Geschichte des Augsburgischen Glaubensbekenntnisses, ed. Wilhelm Gussmann, 2 vols. (Leipzig and Berlin, 1911-1930), 1/1:291-93.

${ }^{37}$ For example, the Landgrave in his instructions to the Hessian embassy to the 1530 Diet. Quellen und Forschungen zur Geschichte des Augsburgischen Glaubensbekenntnisses, 1/1:327-42.

${ }^{38}$ WABr 6:4-10 no. 1766 .

${ }^{39}$ Melanchthons Briefwechsel (hereafter MBW), 11 vols., 6 parts, ed. Heinz Scheible (Stuttgart, 1977-), 2:90 no. 1307, 1308; WABr 6:428-9 no. 1999; MBW 2:252 no. 1739; CR 3:224-29. MBW 2:215 no. 1653, 2:217 no. 1658.

${ }^{40}$ Haug-Moritz, Der Schmalkaldische Bund, 517.

${ }^{41}$ Decretum C. 12 q. ii.70 Corpus Iuris Canonici (hereafter CICan), 2 vols., ed. E. Friedburg (Graz, 1955), 1:710, quoting a famous passage of Ambrose, De officiis ii.140-41. Ambrose, De officiis, ed. and trans. Ivor J. Davidson, 2 vols. (Oxford, 2001), 1:347. See also Decretales Gregorii IX III.xiii.1-III.xix.9, CICan 2:512-25, Liber Sexti III.ix.1-2, CICan 2:1042-3, Liber Clementinarum III.iv.1-2, CICan 2:1160, Extravagantes Johannis XXII III.iv.1, CICan 2:1269, Decretales Gregorii IX III.xlix.2, 4, 7. P. Fourneret, "Biens ecclésiastiques," Dictionnaire de theologie catholique, ed. A. Vacant, E. Mangenot, 16 vols. (Paris, 1908-1972), 2/1:843-78, here 857, 874. But also Alan Gewirth, Marsilius of Padua: The Defender of Peace, 2 vols. (New York, 1956), 2:266-67. A maxim of Pope Boniface VIII summarized the nonrevocability of a gift to the church: "semel deo dicatum non est ad usos humanos ulterius transferendum.” Sexti Decretales, De regulis iuris, li. Sieglerschmidt, Territorialstaat, 113.

${ }^{42}$ Novellae 46, Corpus Iuris Civilis (hereafter CICiv), 3 vols., ed. P. Krueger (Berlin, 1954), 3:280-83. Novellae 120.910, CICiv 3:601-3.
} 
Landgrave was careful to articulate his actions in 1527 in religious terms. ${ }^{43}$ The Elector of Saxony seemed to proceed cautiously, putting confiscated properties under his chancellery only in $1543 .{ }^{44}$ The duke of Braunschweig-Lüneburg contended against several powerful monastic foundations in his territory for years. ${ }^{45}$ City councils that endorsed evangelical preachers-for example Strasbourg, Magdeburg, and Hamburg-struggled with cathedral and collegiate chapters and monasteries, often inconclusively. ${ }^{46}$ Their efforts could look strenuous; their successes, fragile.

The exception was Ulrich of Württemberg. Restored to his duchy in 1534 with the help of the Landgrave, Wittelsbach support, and French money, Ulrich immediately planned the confiscation of church property. In 1535, his officers completed their spectacular sweep through the monasteries of his realm. ${ }^{47}$ One-third of his territory's farmlands were transferred from monasteries to him.

At the League's diet in February 1537 the imperial Vice-Chancellor Matthias Held presented a papal invitation to a general church council, along with a rejection of Protestant complaints against the Imperial Chamber Court. ${ }^{48}$ Tensions among the imperial estates soon escalated with the formation of the Catholic Nuremberg League, preparations for war, and simultaneous initiatives to reach a negotiated settlement within the empire apart from the papacy. There were overtures across the emerging confessional lines. In February 1538, the imperial vicechancellor noted that disputes over church property need not impede negotiations over a ruler's right to promote religion. ${ }^{49}$ The League was, by then, assuming a more aggressive posture in the religious controversy. In advice to the city of Augsburg, where the installation of evangelical preachers in cloister churches in previous years had done little to end monasticism, the League advocated temporal interference in the church without regard to the rights of foreign patrons. ${ }^{50}$

Meanwhile, theologians could hardly overlook the way church incomes had evaporated in Württemberg; and already at the February 1537 diet of the League, the clergy raised the alarm. There Philip Melanchthon presented a petition to the League's princes from "the preachers, subjects, and willing servants, all assembled here." ${ }^{1}$ They begged the League to demand that its estates preserve church and cloister property for reformed churches and schools, and they demanded a unified policy on church property. The League acknowledged the problem a year later, when it asked its members to solicit briefs from theologians. ${ }^{52}$ Why

\footnotetext{
${ }^{43}$ Nicely summarized in instructions to his embassy to the 1530 Diet of Augsburg, note 37, above.

${ }^{44}$ Alfred Hilpert, Die Sequestration der geistlichen Güter in den kursächsischen Landkreisen Meißen, Vogtland und Sachsen 1531-1543 (PhD diss., University of Leipzig, 1911); Inge Mager, "Reformatorische Klosterpolitik im Dienste der Bildung unter besonderer Berücksichtigung der Herzogin Elisabeth von Calenberg-Göttingen und des Herzogs Julius von Braunschweig-Wolfenbüttel," in Kloster und Bildung im Mittelalter, ed. N. Kruppa and J. Wilke (Göttingen, 2006), 561.

${ }^{45}$ Wolfgang Brandis, "Quellen zur Reformationsgeschichte der Lüneburger Frauenklöster," in Studien und Texte zur literarischen und materiellen Kulture der Frauenklöster im späten Mittelalter, ed. Falk Eisermann, Eva Scholtheuber, and Volker Honemann (Leiden, 2004), 357-98.

${ }^{46}$ Ocker, Church Robbers, 94-101 for additional examples and literature.

${ }^{47}$ Martin Brecht and Hermann Ehmer, Südwestdeutsche Reformationsgeschichte (Stuttgart, 1984), 215-22 for a brief overview. The detailed account: Werner-Ulrich Deetjen, Studien zur Württembergischen Kirchenordnung Herzog Ulrichs 1534-1550 (Stuttgart, 1981).

${ }^{48}$ Haug-Moritz, Der Schmalkaldische Bund, 119.

${ }^{49}$ Ibid., 510.

${ }^{50}$ Ibid., 518-19, 524

${ }^{51} 24$ February 1537, MBW, 2:297-98 no. 1853 = CR 3:288-90 no. 1532; Haug-Moritz, Der Schmalkaldische Bund, 530.

${ }^{52}$ F. Roth, "Zur Kirchengüterfrage in der Zeit von 1538 bis 1540," Archiv für Reformationsgeschichte 1 (1903): 299336, here 299-300 n. 3.
} 
ask theologians? The League had to treat church property as a religious problem, and treat the motives for confiscation as religious, to evade demands for restitution.

A handful of these briefs survive. The first came to the League's diet in the summer of 1538 from the Augsburg theologians Wolfgang Musculus and Bonifacius Wolfahrt, and another came from Strasbourg's Martin Bucer. ${ }^{53}$ Both the Augsburg and Strasbourg recommendations are remarkable, but not for their view of the state. To their authors, society was a Christian community with church offices arranged in an evangelical manner. This represents a certain Protestant innovation, but it also allowed for peculiarities of imperial constitution, such as the use of the name "bishop" as a title for a form of temporal rule. More remarkably, these Bibleoriented Protestants used canon law to support evangelical arguments. ${ }^{54}$

Both briefs argued for a concept of spiritual community that precluded temporal dominion. The true possessions of the church, Musculus and Wolfahrt said, were faith, hope, and love: its material things were mere conveniences. ${ }^{55}$ Church property was strictly intended for religious uses. Bucer emphasized the same point. Both documents then argued for a hierarchy of uses of church property: pastoral ministry, schools, poor relief, and, finally, general welfare. This list of uses became standard among the League's theologians. Both briefs took pains to show that this pragmatic-evangelical view of property was not uniquely Protestant. Musculus and Wolfahrt constructed their arguments around meticulous citations of canon and Roman law, and Bucer also relied on canon law to demonstrate the agreement between Protestants and the church's ancient councils.

Theirs was, in short, a self-conscious presentation of evangelical Catholicity. They had noticed the reformist strands of Gratian's Decretum -its use of ancient conciliar decrees and the eleventhcentury reform papacy's condemnations of simony, its support of pastoral ministry by bishops, and its defense of church immunities. Selectively used (which is the only way the Decretum can be used), the canon law supported claims that (1) church property was meant purely to serve true religion, (2) monasteries were supposed to facilitate Christian acculturation, and (3) pastors were not meant to be princes (as in prince-bishops) or personally enfeoffed with church property. Having (selectively) harnessed themselves to the principles of eleventhcentury reform, the authors then marshaled the usual evangelical arguments against papal tyranny and church corruption, pleading for the new faith. Protestants, they insisted, were not church robbers. Corrupt Catholics were. Catholics misused the church's things.

We know that upon this discussion, the League's diet at Eisenach admonished the Protestant estates to avoid the breakup of church property ${ }^{56}$ and we know that theological discussion continued. Bucer's recommendation was sent to Ambrosius Blarer, and Bucer himself was sent to Marburg to show the Landgrave's theologians and jurists how to use church tradition

\footnotetext{
${ }^{53}$ Roth, "Kirchengüterfrage," 299-336; Friedrich Hortleder, Handlungen und Ausschreiben. Von den Ursachen des teutschen Kriegs, book 5, chapter 8, 2 vols., (Gotha, 1645), 2:2002-14; H. Hermelink, "Zwei Aktenstücke über Behandlung der Kirchengüter in Württemberg zur Reformationszeit," Blätter für württembergische Kirchengeschichte, n.s. 7 (1903): 179. The Gutachten is now included in Martin Bucers Deutsche Schriften, $17+$ vols., numerous parts, ed. R. Stupperich (Gütersloh, 1960-), 12: 79-99, along with other relevant texts. For the relationship of the two memoranda, consider Ocker, Church Robbers, 184. See also Gottfried Seebaß, "Martin Bucers Beitrag zu den Diskussionen über die Verwendung der Kirchengüter," in Martin Bucer und das Recht. Beiträge zum internationalem Symposium vom 1. bis 3. März 2001 in der Johannes a Lasco Bibliothek Emden, ed. Christopher Strohm (Geneva, 2002), 167-83.

${ }^{54}$ Ocker, Church Robbers and Reformers, 186-201. For Bucer's use of canon law and his concept of law, see Seebaß in the previous note.

${ }^{55}$ Roth, "Kirchengüterfrage," 317.

${ }^{56}$ Sieglerschmidt, Territorialstaat, 158.
} 
to defend confiscated properties. Bucer then continued to Wittenberg, where he brought another memorandum from his Strasbourg colleague, Wolfgang Capito. ${ }^{57}$ Luther offered his own tired response to Bucer in a letter to Strasbourg. Best to let the matter rest, he said, but admonish church-holders who neglect pastoral care; use Bucer's sources to pressure monks and nuns who are slow to leave cloisters. ${ }^{58}$ Melanchthon sent Strasbourg a more constructive response in essential agreement with Bucer's arguments the same day, adding only that the patrons of churches may use a portion of church property for the common good and to compensate for expenses incurred for the church's sake. ${ }^{59}$ Another recommendation by Bucer was circulated at the League's diet of Frankfurt in April 1539 and by the electoral princes of Brandenburg and the Palatinate, who were attempting to build a peace party across confessional lines. ${ }^{60}$ In 129 paragraphs, this recommendation defended the temporal ruler's obligation to reform the church; identified the true church with correct doctrine, a correct practice of sacraments, and a correct exercise of discipline; allowed for secular uses of church property; and argued that prince-bishops be replaced by lay officers. It frequently invoked canon law by name without ever citing particular laws. It seems to presuppose the canonical arguments Musculus, Wolfahrt, and Bucer had earlier made.

In April 1539, it was agreed to negotiate the religious controversy at the imperial Diet (resulting in the Truce of Frankfurt). This must have unsettled everyone. As the League's meeting in December of that year approached, the Landgrave worried that Protestant theologians would undermine confiscations. ${ }^{61}$ At the meeting itself, the Elector of Saxony worried that a negotiated settlement would freeze the reformation and prevent new gains (he was soon to try to install an evangelical into the bishopric of Naumburg). ${ }^{62}$ Duke Ulrich of Württemberg worried that princely rights would be compromised. ${ }^{63}$ The city of Ulm complained that supporting clergy was costing them thousands of gulden. ${ }^{64}$ Princes pleaded that questions about church property be left to the consciences of rulers. ${ }^{65}$ The cities demanded that the League take a common position. ${ }^{66}$ And the League did.

The League reached and published a common position on church property at its next meeting, at Schmalkalden in March and April 1540. ${ }^{67}$ Theologians representing the two Saxonies, Hesse, Nassau, Strasbourg, Magdeburg, and Bremen were assembled to approve a recommendation authored by Melanchthon on 9 March $1540 .{ }^{68}$ The recommendation made

\footnotetext{
${ }^{57}$ Der Briefwechsel des Justus Jonas, ed. Gustav Kawerau, 2 vols. (Hildesheim, 1964 reprint of the Halle, 1884-1885 edition), 1:305.

${ }^{58}$ WABr 8:325-26 no. 3275 .

${ }^{59} \mathrm{CR}$ 3:608-9 no. 1752 .

${ }^{60}$ Haug-Moritz, Der Schmalkaldische Bund, 113, 193, 531 n. 11; Stadtarchiv Ulm, A1214, ff. 576-618, discussed in Ocker, Church Robbers and Reformers, 202-9, and now identified as a work of Martin Bucer and edited by Stephen Buckwalter in Martin Bucers Deutsche Schriften, 12:151-85.

${ }^{61}$ In his instructions to his embassy to the League's diet of 5 November 1539. Günther Franz, Urkundliche Quellen zur hessischen Reformationsgeschichte, 3 vols. (Marburg, 1954), 2:322-23 no. 399.

${ }^{62}$ Haug-Moritz, Der Schmalkaldische Bund, 520-21.

${ }^{63}$ Hermelink, "Zwei Aktenstücke," 180.

${ }^{64}$ Haug-Moritz, Der Schmalkaldische Bund, 523.

${ }^{65}$ Ibid., 524.

${ }^{66}$ Ibid., 534-35; Akten der deutschen Reichsreligionsgespräche im 16. Jahrhundert, 2+ vols., ed. Klaus Ganzer and Karl-Heinz zur Mühlen (Göttingen, $2000+$ ), 1/2:1127-28 no. 395.

${ }^{67}$ For Catholic and Protestant maneuvering before that meeting, see Ocker, Church Robbers, 216-23.

${ }^{68}$ Melanchthon, Epistolae, iudicia, consilia, testimonia aliorumque ad eum epsitolae quae in Corpore Reformatorum desiderantur, ed. Heinrich Ernst Bindseil (Halle, 1874; reprint Hildesheim, 1975), 142-46; Martin Bucers Deutsche Schriften, 9/1:79-90. Ocker, Church Robbers, appendix 1.
} 
six simple points, all of which had variously appeared in the memoranda of the last two years: (1) that rulers must reform the church, (2) that church property must serve the locality for which it had been given, (3) that a church income must remain with the office for which it had been given (i.e., is not a personal possession of an incompetent pastor who has been removed), (4) that church property belongs to the community, (5) that property cannot be taken from the church, and (6) that cities and princes should get along. These points were presented to the League's estates on 11 March and discussed on 13 and 14 March.

A clause for the diet's recess on church property was drafted two days later. ${ }^{69}$ The final version of the diet's recess emphasized how the League had consulted theologians, and it emphasized religion. It stated a government's obligation to fulfill its religious obligations: by appointing God-fearing men to church offices, educating the youth, caring for the poor, and correcting religious practices. Church property was to be used to support pastors, preachers, and ministers who preach and propagate God's word; to prepare youth for church offices; and to help the poor. The members of the League promised to establish hospitals and common chests, offer aid to poor students, both noble and common, and give pensions to retired clergy. Whatever monies then remained would be used to the advantage of good government and God. ${ }^{70}$

As the League reached its common position on church property, negotiations for a German settlement to the religious controversy continued. This is where the true force of the League's discussion of church property can best be seen. An official invitation to an imperial religious colloquy was sent to the League's diet at Schmalkalden, and the League's official response was approved on 11 April 1540 and sent under the names of the Landgrave and the Elector of Saxony to Nicholas Perrenot de Granvelle, the imperial chancellor; it was produced in German, Latin, and French versions (John Calvin provided the French translation for the emperor $)^{71}$

The response began in a studied irenic tone, then quickly switched to a diatribe on church property. It accused Catholics of church robbery, insisted on the religious sincerity of Protestant actions, and claimed that Protestants converted monastic properties to new charitable uses only after monks and nuns voluntarily abandoned these properties in response to evangelical preaching, in obedience to the gospel. The response claimed that new property administrators were then appointed (they were surely mindful that cities and princes had been appointing such administrators in the name of reform for over a century). Protestant princes, the Landgrave and Elector argued, only wanted to assure good management of church property. The Imperial Chamber Court's actions against the League's members were entirely unjust, shielded corrupt clergy, and threatened to undermine the churches' civilizing role and ruin human society. Only after the diatribe on church property did the authors turn to the doctrinal disagreements between the new faith and the old.

The League's response to the imperial invitation to a religious colloquy must have fascinated Granvelle. To date, the Emperor Charles V had himself been an extraordinarily effective user of

\footnotetext{
${ }^{69}$ Staatsarchiv Marburg Beistand 3 No. 538, ff. 59r-60v and Ocker, Church Robbers, 228-29 n. 49.

${ }^{70}$ Roth, "Kirchengüterfrage," 301-2. Akten der deutschen Reichsreligionsgespräche, 2:1105-6 no. 393.

${ }^{71}$ Martin Bucers Deutsche Schriften, 9/1:80; Johannes Calvin, Ep. 218, CR 38/2:39. A shortened version was first printed at Granvelle's request. It is reproduced in Hortleder, Ursachen, book 1, chapter 5, 1:1124. The longer, original version, in German translation, may be found in Martin Luther, Sämmtliche Schriften, ed. Johann Georg Walch, 23 vols. (St. Louis, 1901), 17:338-53; Akten der deutschen Reichsreligionsgespräche 1/1:81-89 no. 21 (the Latin version). See also CR 3:989. The pamphlet version: Johann Friedrich I and Philipp Landgraf, Responsio, quam in causa religionis dedimus ad instructionen, quae allata est Smalcaldiam (Wittenberg, 1540), Flugschriften des späteren 16. Jahrhunderts fiche 1007 no. 1766.
} 
church property, as Jacob Fühner recently showed in a detailed study of the Netherlands. Charles had repeatedly won portions of all church benefices in Dutch realms, and he temporarily confiscated properties of the ten largest monasteries of Flanders. He took over the temporal domain of the bishop of Utrecht and was well on his way to controlling the bishoprics of Utrecht, Lüttich, Arras, Tournai, and Cambrai (which he accomplished by the end of his life). All of this encroachment had to be, to one extent or another, negotiated with Rome. $^{72}$ Protestants knew that Granvelle was hardly prudish about church property (the anonymous memorandum of the League's diet of Frankfurt in 1539 noted that Charles used ecclesiastical incomes to pay Granvelle). ${ }^{73}$ Some Catholics followed the rekindling of religious negotiations in Germany with concern. Pope Paul III noticed that Protestants meant to evade discussion of church property by taking advantage of the emperor's desperation to build up his anti-Turkish army with German soldiers. ${ }^{74}$ The papal nuncio to King Ferdinand, Giovanni Marone, feared that all of Germany was about to be lost. ${ }^{75}$ They may have underestimated Charles's Catholicism. But they were right about the danger to church property.

The famous Regensburg Colloquy came and went without addressing church property, just as the League had insisted. After it, two Protestant memoranda, one anonymous and one by Melanchthon, repeated the grounds for ending suits against Protestant confiscators and justifying Protestant uses of church property. ${ }^{76}$ Cardinal Gasparo Contarini signaled the readiness of Catholics themselves to redistribute church properties to schools (essential to the growth of Jesuit and Capuchin schools later in the century). ${ }^{77}$ And the emperor secretly promised to respect Protestant acquisitions. ${ }^{78}$ The League's final effort to recuse the Imperial Chamber Court came in 1542, with the court suspended in 1543-1544. ${ }^{79}$ The court's suspension tacitly validated Protestant claims to reorganize churches and their properties for religious, rather than secular, ends. The religious controversy continued. The colloquies failed. The Elector's ambitions weakened the League. The League lost the war in 1547.

But ultimately, how much did this really matter to the survival of the new faith? What exactly had the Protestants been aiming for? From 1538 to 1545, it was difficult to know if the League hoped to win acceptance of the new church within the imperial Diet or establish a counter-diet, a counter-empire. The theologians had their religious purposes. They aimed to free the church of abuses. Although they knew that the ambitions of princes and ruling elites could undermine their cause, the theologians expected princes and city councils to support them; these theologians also recognized that evangelical security required some political compromises. And maybe they always expected the apocalypse that the war of 1546-1547 promised to deliver. ${ }^{80}$ But the tacit acceptance of Protestant property claims meant the new church would survive.

\footnotetext{
${ }^{72}$ Fühner, Die Kirchen- und die antireformatorische Religionspolitik, 89-165.

${ }^{73}$ The memorandum of note 60 , above.

${ }^{74}$ Luther, Sämmtliche Schriften, 17:364-72.

${ }^{75}$ Elisabeth Gleason, Gasparo Contarini: Venice, Rome, and Reform (Berkeley, 1993), 203.

${ }^{76}$ Luther, Sämmtliche Schriften, 17:707-30 no. 1384.

${ }^{77}$ Ibid, 17:734-36 no. 1387; CR 4:507; Henze, “Orden und ihre Klöster," 99-102.

${ }^{78}$ Fuchs, Konfession und Gespräch, 452.

${ }^{79}$ Brady, Protestant Politics, 249-327; Sieglerschmidt, Territorialstaat, 156, 159.

${ }^{80}$ Brady, Protestant Politics, 306-7; Robin Bruce Barnes, Prophecy and Gnosis: Apocalypticism in the Wake of the Lutheran Reformation (Palo Alto, 1988), 60-99.
} 


\section{The Unresolved State of Religion}

There is a tendency to associate confiscations of church property with the progress of confessional states and territorial churches. But to participants, the religious controversy in Germany had another elusive goal-the restoration of true religion. In the first generation of Protestants, the most that a discerning observer could see, amid the ongoing struggle to advance the new faith in territories and cities, was a serendipitous movement toward an empire of two churches.

For religion's political landscape was hard. It changed slowly. Princes still exercised personal dominion, in spite of a gradual, tectonic movement toward full-fledged states. Clergy still claimed church privileges, even if temporal guardians were henceforth the guarantors of the authenticity of religious communities. In this landscape, the new faith's position was soft. The tenacity of some old religious foundations in many places whose rulers were committed to the Augsburg Confession kept the confessional solidity of many Protestant territories an open question. Luther's heresy survived in an officially Catholic imperial polity. The old faith survived in evangelical territories. This mixed circumstance could be found to one degree or another in most places; it points to a continued intermingling of Protestant and Catholic networks of patronage and support.

Sixteenth-century bi-confessional churches and the simultaneum, a church building shared by two confessions, established in numerous cities and territories after the Peace of Westphalia (some 64 "simultaneous churches" still exist in Germany today), provide the most obvious evidence of the compromises to which the process of territorial confessionalization was repeatedly subjected since the beginning of the Reformation and throughout the early modern period. ${ }^{81}$ The fact of an inconclusive German Reformation is obscured if one focuses only on the most comprehensive territorial conversions: Prussia at the periphery of the Holy Roman Empire and Hesse at the center of Germany in the late 1520s, Württemberg in the mid 1530s, or the most Protestant moments in cities like Magdeburg or Halberstadt. In Magdeburg, Franciscans abandoned town in February 1542 when alms had declined and could no longer sustain the friars who had survived there. They left by pairs praying the Rosary. The Carmelites handed their cloister over to the Old City council in 1545, the Penitents of Mary Magdalene in 1546, and the remaining orders during the Schmalkald War in 1546-1547. In Halberstadt during the Schmalkald War, the council confiscated cloisters, sending a regiment of bare-breasted women dancing and grabbing their way through the Franciscan refectory (the council presented the friars with secular garments made out of their own altar cloths). ${ }^{82}$

Events like these at Magdeburg or Halberstadt belonged to seasons of unusual confessional clarity. Confessional ambivalence was as real and in many regions more prevalent at the height

\footnotetext{
${ }^{81}$ Wim Blockmans, Emperor Charles V, 1500-1558, trans. Isola van den Hoven-Vardon (New York, 2002), 97; Helmut Neumaier, "Simultaneum und Religionsfrieden im Alten Reich. Zu Phänomenologie und Typologie eines umkämpften Rechtsinstituts," Historisches Jahrbuch 128(2008): 137-76; Randolph C. Head, "Fragmented Dominion, Fragmented Churches: The Institutionalization of the Landfrieden in the Thurgau, 1531-1610," Archiv für Reformationsgeschichte 96 (2005): 126-34; Tom Scott, Town, Country, and Regions in Reformation Germany (Leiden, 2005), 62-63; Daniela Hacke, "Der Kirchenraum als politischer Handlungsraum: Konflikte um die liturgische Ausstattung von Dorfkirchen in der Eidgenossenschaft der Frühen Neuzeit," Konfessionen im Kirchenraum. Dimensionen des Sakralraums in der Frühen Neuzeit, ed. Susanne Wegmann, Gabriele Wimböck (Korb, 2007), 137-58. For simultaneous churches today, see Heinz Henke, Wohngemeinschaften unter deutschen Kirchendächern: Die simultanen Kirchenverhältnisse in Deutschland - eine Bestandsaufnahme (Leipzig, 2008).

${ }^{82}$ Franz Schrader, Ringen, Untergang und Überleben der katholischen Klöster in den Hochstiften Magdeburg und Halberstadt von der Reformation bis zum Westfälischen Frieden (Münster, 1977), 30-31.
} 
of the religious controversy, in the early 1540s, when the League of Schmalkalden was in its most politically ambitious phase. Accordingly, a French observer of the religious colloquies of 1540 and 1541, John Calvin, in letters to his friend Guillaume Farel, lauding the Protestant Johann Friedrich's belligerence, worried about Protestants who would compromise reform. He was troubled by the genuine possibility of religious peace! ${ }^{83}$ Prominent men believed in the marriage of reform and an imperial peace, including the evangelical theologian Martin Bucer and the Catholic Johannes Wild (cathedral preacher in Mainz), the electors of Brandenburg and the Palatinate, the bishop of Münster and Osnabrück, and the emperor himself.

The unresolved state of religion defines the German Reformation, reminding us that religious norms were more easily argued by theologians than uniformly followed by society at large. Perhaps the simplest way to observe this condition is to consider monasticism. Monasticism is relevant to us for the simple reason that monasteries were landholders, sometimes very great landholders, and hence they fragmented the dominions of the European historian's much-anticipated confessional states. The new faith rebutted the most compelling reason to become a monk or a nun-to save one's soul and the souls of others. This rebuttal coincided with, and surely abetted, widespread attrition in monasteries. Yet many monasteries survived. What does this say about Reformation-era Christianity?

It points, for one, to the fact that not every ruler followed a confessionally predictable script. The evangelical Duchess Elisabeth of Calenberg-Göttingen introduced an evangelical order for cloisters, but this order preserved both the divine office (a Catholic regimen of monastic prayer) and monastic property. In contrast, her Catholic son Erich, though anxious to return churches in his territory to Catholic obedience, burdened monasteries with mortgages and excises, treating them as though they belonged to his fisc. ${ }^{84}$ On the other hand, a Protestant duke could cover his infringement of some rights by claiming to guard others. The six women's monasteries of the duchy of Lüneburg lost some part of their incomes in 1529 and 1530. Duke Erich replaced their provosts with his own unilaterally appointed procurators, confiscated whatever account documents his men could lay their hands on, tried to take over incomes, liquidated property without the monasteries' consent, and placed the nuns on state welfare. But he did this as protector, guaranteeing traditional rights and prerogatives, as the alarmed nuns at Wienhausen, Isenhagen, and Lüne carefully noted in their chronicles. ${ }^{85}$ The memory of the rebellions of 1524-1525 provided other pretexts for state encroachment. At the Cistercian monastery of Wienhausen in 1529, the monastery's provost claimed to confiscate documents on Duke Erich's behalf for their protection, in case the monastery were destroyed in a peasants' war. $^{86}$

\footnotetext{
${ }^{83}$ C. Ocker, "Calvin in Germany," in Politics and Reformations: Histories and Reformations-Essays in Honor of Thomas A. Brady, Jr., ed. C. Ocker, M. Printy, P. Starenko, and P. Wallace (Leiden, 2007), 332-33. Consider also, Bodo Nischan, Prince, People, and Confession: The Second Reformation in Brandenburg (Philadelphia, 1994), 5-33; Estes, Peace, Order, and the Glory of God, 138-52; Horst Rabe, Reichsbund und Interim. Die Verfassungs- und Religionspolitik Karls V. und der Reichstag von Augsburg 1547/1548 (Cologne, 1971), 260-72; Albrecht Pius Luttenberger, Glaubenseinheit und Reichsfriede. Konzeptionen und Wege konfessionsneutraler Reichspolitik 15301552 (Kurpfalz, Jülich, Kurbrandenburg) (Göttingen, 1982), 425-501; Thomas Berger, "Johannes Wild (14951554)," Katholische Theologen der Reformationszeit, 6 vols. (Münster, 1984-2004), 6:110-31.

${ }^{84}$ Mager, "Reformatorische Klosterpolitik," 565.

${ }^{85}$ Brandis, "Quellen," 357-98, with excerpts from the Wienhausen and Lüne chronicles.

${ }^{86}$ Brandis, "Quellen," 367. The same provost had a history of liquidating monastery properties without the convent's approval over the previous five years. The properties were: a stud farm, four horses and three oxen with tackle, twelve young steer, thirty-two cows, large numbers of pigs (160 in 1525, 120 in 1528), etc. Brandis, "Quellen," 393-94.
} 
But nuns were tenacious. At Lüne and Wienhausen, they resisted the harangues of the duke's preachers and the personal admonitions of the duke. Unwilling to leave the monastery, deprived of the Catholic sacraments, and subjected to a Lutheran divine office in German, the community eventually converted by default. At Lüne, their resistance weakened after $1535 .{ }^{87} \mathrm{At}$ Wienhausen, in contrast, the last Catholic abbess came to office as late as $1565 .{ }^{88}$ All six Lüneburg women's monasteries continue to exist to the present day as Protestant convents. Their properties were never completely liquidated; and although long "converted," they remembered their Catholic past sympathetically. ${ }^{89}$

Monks were tenacious, too, even while gradually converting. Far to the south, in the margraviate of Ansbach-Kulmbach, the Cistercian monastery of Heilsbronn, first subjected to evangelical reforms in 1524, still thought of itself as Cistercian, long after its formal (papally approved) conversion to a collegiate foundation and long after abandoning the Cistercian habit. A brief restoration of the monastery to Cistercian control in 1549 must have seemed natural. The margrave of Ansbach-Kulmbach did not gain complete control of the cloister's properties until $1578 .^{90}$

Evangelical rulers accepted compromises with Catholic foundations. The cities of Strasbourg and Magdeburg reached compromises with their cathedrals by $1534 .^{91}$ It took decades to control monasteries in the principalities of Magdeburg and Halberstadt in the second half of the sixteenth century. ${ }^{92}$ The cities of Hamburg and Augsburg managed to force their cathedral chapters out of town walls, but they could not control all cathedral assets, however much they thought they should. In Hamburg, the controversy over the chapter's right to self-rule droned on to 1561 and ended in compromise. ${ }^{93}$ The city of Halberstadt's evangelically sympathetic council failed to control religious life in the town until 1539, when it began a concerted effort to do so, an effort that lasted until the defeat of the Schmalkald League (1547). ${ }^{94}$ Even Basel, scene of one of the most revolutionary endings of urban Catholicism in 1529, struggled intermittently for over a century against the claims of its exiled cathedral chapter. ${ }^{95}$

Notwithstanding such compromises, the greatest losers of the Reformation were without doubt religious foundations, and yet many survived. Even a rough survey of losses is highly instructive. Let us consider eight examples on the grand scale of the empire as a whole: the most pervasive form of corporate church (collegiate foundations), an old order generally rich in lands (Benedictines), two high-medieval reform orders (Carthusians and Cistercians), two military orders (Teutonic Knights and Hospitallers of Saint John), and two mendicant orders (Carmelites and Augustinian Hermits).

\footnotetext{
${ }^{87}$ Brandis, “Quellen,” p. 371.

${ }^{88}$ Ibid., 364.

${ }^{89}$ Ibid., 391.

${ }^{90}$ Manfred Sitzmann, Mönchtum und Reformation. Zur Geschichte monastischer Institutionen in protestantischen Territorien (Brandenburg-Ansbach/Kulmbach, Magdeburg), (Neustadt a.d. Aisch, 1999), 80-170.

${ }^{91}$ Lorna Jane Abray, The People's Reformation: Magistrates, Clergy and Commons in Strasbourg, 1500-1598 (Ithaca, NY, 1985), 42.

${ }^{92}$ Schrader, Reformation und katholische Klöster, 85-138, 164-222.

${ }^{93}$ Herbert Immenkötter, "Die katholische Kirche in Augsburg in der ersten Hälfte des 16. Jahrhundert," Die Augsburger Kirchenordnung von 1537 und ihr Umfelfd, ed. Reinhard Schwarz (Gütersloh, 1988), 9-32; Otto Scheib, Die Reformationsdiskussionen in der Hansestadt Hamburg, 1522-1528 (Münster, 1975), 180-88.

${ }^{94}$ Silke Logemann, "Grundzüge der Geschichte der Stadt Halberstadt vom 13. Bis 16. Jahrhundert," in Bürger, Bettelmönche und Bischöfe in Halberstadt. Studien zur Geschichte der Stadt, der Mendikanten und des Bistums vom Mittelalter bis zur Frühen Neuzeit, ed. Dieter Berg (Werl, 1997), 81-138, here 128-38.

${ }^{95}$ Paul Roth, Durchbruch und Festsetzung der Reformation in Basel (Basel, 1942), 71-79.
} 
Of the 500 collegiate foundations of the Holy Roman Empire, 79 were closed or converted to Protestantism by 1548; an additional 2 were closed by Catholic authorities (their personnel and property combined to another foundation or incorporated to a religious order; 84 percent survived). ${ }^{96}$ At least 6 foundations were obliged to divide canonries between both confessions or to share the church. ${ }^{97}$ Only 14 collegiate foundations converted or were closed between 1549 and 1565, just before the iconoclastic "wonder year" in the Habsburg Netherlands. Between 1565 and 1600, another 56 converted or were closed, many in connection with the Dutch Revolt. By contrast, of those 500 foundations of 1520, 253 would meet their end in the French Revolution or the Napoleonic invasion (counting the years 1789-1811). Only 5 had fallen to the Hussites a century before Luther's rebellion against the pope. $^{98}$

Of the 214 Benedictine monasteries for men in the German-speaking areas of the Holy Roman Empire, 132 survived the sixteenth century (61 percent), 79 closed during the religious controversy, and an additional 3 closed and reopened in the seventeenth century. ${ }^{99}$ Benedictine women's monasteries fared worse. Of the 164 Benedictine monasteries for women, 60 survived the sixteenth century (36.6 percent), 102 closed, and 1 closed and was reestablished in the seventeenth century.

The Carthusian order, which had experienced its greatest growth in Central Europe during the two hundred years before Luther, lost 15 of the 56 of the cloisters established in the Holy Roman Empire before 1500, as a result of sequestration or similar actions by evangelical authorities between the beginning of the religious controversy and 1555 (73 percent survived). ${ }^{100}$ One to five years of inventory, confiscation of documents, reassignment of properties, and pensioning of monks preceded most closures. ${ }^{101}$ Six additional Carthusian monasteries closed between 1556 and $1600 .{ }^{102}$ In contrast, 1 had been destroyed by the Hussites in the fifteenth century, and 1 closed in the seventeenth century. ${ }^{103}$

\footnotetext{
${ }^{96}$ Alfred Wendehorst and Stefan Benz, Verzeichnis der Säkularkanonikerstifte der Reichskirche (Neudstadt an der Aisch, 1997), passim.

${ }^{97}$ Wendehorst and Benz, Verzeichnis, s.v. Bielefeld, Herford, Minden, Möckmühl, Soest, Wetzlar.

${ }^{98}$ Ibid., s.v. Grossenhain/Ozzek, Karlstein/Karlštein, Lipnitz/Lipnice, Melnik/Mělník, Moldauthein/Týn and Vltavou.

${ }^{99}$ For this and the following, see Friedhelm Jürgensmeier and Regina Elisabeth Schwerdtfeger, eds., Orden und Klöster im Zeitalter von Reformation und katholischer Reform 1500-1700, 3 vols. (Münster, 2005-2007), 1:14-16, 50-52, 76-77, 102-5, 128-29, 144-45.

${ }^{100}$ The following information is compiled from Gerhard Schlegel and James Hogg, eds., Monasticon Cartusiense, vol. 2 (Salzburg, 2004), passim. Nürnberg 1525, Mariefred 1526 (by the King of Sweden), Eppenberg 1527, Bern 1528, Eisenach 1529, Konradsburg 1530, Crimmitschau 1531, Güterstein 1535, Frankfurt (Oder) 1540, Letanovcde 1543, Legnica 1548, Darłowo 1548, Szczecin (Stettin) 1551, Lövöld 1552, Świdwin (Schivelbein) 1552.

${ }^{101}$ See Monasticon Cartusiense vol. 2, s.v. Nürnberg, Eppenberg, Eisenach, Konradsburg, Crimmitschau, Güterstein, Frankfurt (Oder) (but it took 8 years at Legnica and 13 years at Szczecin and Świdwin).

${ }^{102}$ Rostock 1557, Basel 1564, Ahrensbök 1564, Wesel 1590, Strasbourg 1591, Pleterje 1595.

${ }^{103}$ Prague closed in 1419. But another 4 Carthusian monasteries were plundered in the Hussite wars: Frankfurt (Oder) 1432, Letanovce 1433, Brno 1428, Olomouc 1425 and 1437. In other wars, Kartuzy (Danzig) was plundered during the conflict between the Teutonic Order and the Pommerellenstädtebund in 1455, in 1458 by Polish troops, and in 1466 by the Teutonic Order. Mauerbach, in 1462, was plundered by the Austrian duke and in the 1480s by the Hungarians, then in 1529 by the Turks, in 1619 by the Bohemians, and again in 1683 by the Turks. The seventeenth closure was Christgarten (Nördlingen) in 1648. But 36 Carthusian monasteries were secularized between 1772 and 1848, the majority in 1802-1803. Kartuzy (Danzig) 1772, Hildesheim 1777, Jurklošter (Gairach) 1780, Mainz 1781, Žiče (Seitz) 1782, Bistra (Freudenthal) 1782, Lechnic (Lechnitz) 1782, Mauerbach 1782, Gaming 1782, Brno 1782, Aggsbach 1782, Olomouc (Olmütz)-Dolany 1782, Schnals 1782, Freiburg (Briesgau) 1782, Valdice 1782, Roermond 1783, Molsheim 1791, Rettel 1792, Koblenz 1802, Trier 1802, Köln 1802, Vogelsang 1802,
} 
Of the 121 Cistercian monasteries for men, 68 survived (56 percent), 50 closed, and another 3 closed and reopened in the seventeenth century. Of 255 Cistercian monasteries for women, 82 survived (32 percent), 163 closed, 4 more closed and reopened in the sixteenth century, and another 6 closed and were reestablished in the seventeenth century. Of the 124 commanderies of the Teutonic Knights, 73 survived (58 percent), 25 closed, 1 more closed and was reestablished in the seventeenth century, whereas another 14 commanderies became Lutheran and another 11 (in the Netherlands) became Reformed. Of 124 commanderies of the Hospitallers of Saint John, 85 survived (62 percent) and 34 closed, with another 10 closing and later reopening, whereas 9 became Protestant.

Ninety-six of the 160 cloisters of the German provinces of the Augustinian Hermits (which included regions east, south, and west of Germany today) were closed during the religious controversy (40 percent survived the century). ${ }^{104}$ The provinces that covered Luther's area of immediate influence, Saxony and Thuringia, together with the Reformed Congregation led by Luther's close friends Johannes Stauptiz and then Wenzeslaus Linck, were the most strongly affected (both provinces ceased to exist in the Reformation, their surviving convents incorporated into other provinces). They lost 35 cloisters from 1523 to 1538, largely as a result of the Luther controversy, ${ }^{105}$ and another 9 after the Protestant conversion of Albertine Saxony and Brandenburg. ${ }^{106}$ The Bavarian province lost 18 cloisters, 6 before 1538 and another 6 up to $1548 .^{107}$ The vast majority of Augustinian Hermit houses closed when incomes had fallen below sustainable levels or their membership dwindled, reflecting an impact of evangelical doctrine. Such attrition also affected cloisters that managed to keep their doors open. Luther's order reflects an extreme point on the scale of Protestant impact on monasticism: his influence on monks was most strongly felt in his own religious order.

The Carmelites were a much smaller order in Germany. Of the 24 cloisters of the Carmelite province of Upper Germany, which extended from southwest Hungary through Austria, Bavaria, and Franconia into Swabia, 8 were closed as a result of the evangelical movement (77 percent survived). ${ }^{108}$ An additional cloister closed through attrition, but there is no known connection of this to evangelical preaching (Gösing, 1548). Another was relocated to

Xanten 1802, Grünau 1803, Würzburg 1803, Tückelhausen 1803, Erfurt 1803, Buxheim 1803, Astheim 1803, Ilmbach 1803, Prüll (Regensburg) 1803, Weddern 1804, Gidle 1819, Bereza 1831, Ittingen 1848.

${ }^{104}$ Adalbero Kunzelmann, Geschichte der deutschen Augustinereremiten, 7 vols., (Würzburg, 1969-1979), 5:516-18. See also, Ibid., 6:1-8 and 7:113-62.

${ }^{105}$ Eight from 1523 to 1524 (in no particular order): Gewitsch, Zürich, Antwerp, Eisleben, Sternberg, Rössel, Quedlinburg, Patollen. 11 in 1525 alone: Wittenberg, Erfurt (but restored within months, only to die out in 1560), Königsberg i.Fr., Himmelpforten, Windesheim, Magdeburg, Neustadt a.O., Herzberg, Gotha, Zerbst, Nürnberg. Fifteen from 1526 to 1538, the period from the end of the Peasants' War to just before the second expansion of the League of Schmalkalden: Helmstedt, Alsfeld, Eschwege, Gartz a.O., Anklam, Kulmbach, Grimma, Constance, Tübingen, Neustettin, Stargard, Königsberg i.N., Königsberg i.N., Wilster, Friedeberg.

${ }^{106}$ From the second expansion of the League after 1537 through its defeat in 1547 and to the Leipzig Interim in 1548 : Einbeck, Sangerhausen, Waldheim, Langensalza, Dresden, Schmalkalden, Herford, Osnabrück, Lippstadt, Appingedam.

${ }^{107}$ Nürnberg 1525, Windsheim 1525, Mindelheim 1526, Klosterneuburg 1529, Memmingen 1531-8, Marchegg 1537, Radkersburg 1542, Kornenburg 1545, Baden bei Wien 1545, Judenburg 1545, Bruck an der Leithe 1546, Kulmbach 1547, Ramsau 1549, Hohenmauthen 1549, Völkermarkt 1550, Laibach 1555, Schönthal 1559, Rattenberg 1560, not including the cloisters of Silesia, which were all lost as a result of Prussian secularization. Ibid., 3:51-63.

${ }^{108}$ Nürnberg 1525, Neustadt/Kulm 1527, Esslingen 1531-1536, Augsburg 1534, Heilbronn 1535, Sparneck 1537, Rothenburg am Neckar 1538, Nördlingen 1538. 
Vienna due to the Turkish occupation of parts of Hungary (Fünfkirchen), and another was destroyed in the Turkish occupation (Priwitz). ${ }^{109}$

Although these are not really commensurable numbers, and I have not explained their variability, they illustrate a simple point: the Reformation was an unresolved controversy, an undecided contest, and the inconclusive state of religion would determine the Reformation's future. In small places, the closure of an old foundation generally represents a moment at which declining membership or loss of income reached such a miserable point that intervention by a temporal ruler, acting as guardian of church property, the guarantor of its ongoing religious uses, was justifiable. In small places, the survival of a foundation can represent a religious community's ability to resist interference, or it can represent the presence of old-faith guardians. In either case, the survival of a monastery points to the importance of a social environment in confessional debate. If one considers that social environment on the grand scale-the cumulative experience of the burghers, councils, seigneurs, nobles, and princes who participated in the management of churches and cloistersone sees that Protestant and Catholic arguments for reform proved inconclusive. The uncertainties created by this must have contributed mightily to doubts about the value of traditional religious institutions, but not to the elimination of religious orders as early Protestants had expected. Yet in the sixteenth century, there was agreement across the board on the cause of monastic decline. Protestants and Catholics both said it was the new faith. Protestants claimed that monastic attrition was an effect of evangelical preaching. Catholics claimed that it was an effect of Luther's heresy. The clarity of this polemic is muddled by the panorama of sixteenth-century cloisters, whose closures and conversions prove how hard it was, in real life, to win confessional battles.

This brings us to a large place, the empire, and the grand sweep of time. We know that the events of the sixteenth century could not prevent an eventual resurgence of monasticism in the seventeenth and eighteenth centuries, and monastic losses in the Reformation cannot compare even remotely to the state-sponsored secularizations of $1780-1830 .{ }^{110}$ Could Protestants really have hoped for an empire of the new faith? The fact that churches of the Augsburg Confession survived at all owes everything to the empire's de facto recognition of them, achieved by an arduous political process. Acceptance of Protestant confiscations of church property rested on claims about the religious uses of property, defined by canon law and tradition and reinterpreted by the new clergy to support the Protestant ministry. It just happened that clerical rhetoric, meant to win church property for evangelicals and protect it from abuse by temporal rulers, helped the League justify its actions as protection of the church. It was in this unexpected way that the faith of the new theologians created an empire of two churches.

\footnotetext{
${ }^{109}$ Of the 24 cloisters of the Carmelite province of Upper Germany, which extended from southwest Hungary through Austria, Bavaria, and Franconia into Swabia, 8 were closed as a result of the evangelical movement (Nürnberg 1525, Neustadt (Kulm) 1527, Esslingen 1531-1536, Augsburg 1534, Heilbronn 1535, Sparneck 1537, Rothenburg am Neckar 1538, Nördlingen 1538). An additional cloister died of attrition with no apparent connection to evangelical preaching (Gösing, 1548), another was relocated to Vienna due to the Turkish occupation of parts of Hungary (Fünfkirchen), and another was destroyed in the Turkish occupation (Priwitz). Adalbert Deckert and Matthäus Hösler, Acta des Karmelitenprovinzials Andreas Stoss (1534-1538) (Rome, 1995), 46-112.

${ }^{110}$ Derek Beales, Prosperity and Plunder: European Catholic Monasteries in the Age of Revolution, 1650-1815 (Cambridge, 2003), passim.
} 
Christopher Ocker is Professor of Church History at the San Francisco Theological Seminary, San Anselmo, CA 94960. An earlier version of this essay was read before the conference "Religion and Authority in Central Europe" at the University of Alberta in September 2006. My thanks go to Howard Louthan and the other participants for their comments and to Joshua Kortbein of the Center for Austrian Studies at the University of Minnesota for his careful editorial review. 